\title{
CORRESPONDENCE
}

Gynaecological laparoscopy

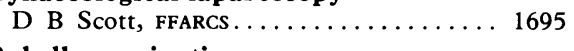

Rubella vaccination

R Pilsworth, MD, and Barbara J Pilsworth

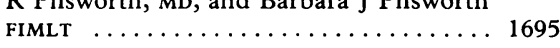

Epidemic myalgic encephalomyelitis

H G Easton, MD ............... 1696

Improvement of perinatal care

J A Davis, FRCP................ 1696

How much physical therapy for patients with stroke?

J Knox, MRCPED, and P Horrocks, FRCP;

J C Brocklehurst, FRCPED and K Andrews,

MRCP $\ldots \ldots \ldots \ldots \ldots \ldots \ldots \ldots \ldots \ldots . \ldots \ldots$

Histamine release in exercise-induced asthma

Linda Ferris, BSC, and others. . . . . . . . . . 1697

Confusion about New Zealand abortion?

H C McLaren, FRCOG. . . . . . . . . . . . . . 1697

Carcinoma of the male breast and

oestrogen metabolism

D B Jefferys, $M B$, and J Efthimiou, $M B$;

R Abele, MD, and others. . . . . . . . . . . 1697

So we'll go no more a-jogging

A W Fowler, FRCS; N Harris . . . . . . . . 1698
Urinary incontinence during treatment with depot phenothiazines

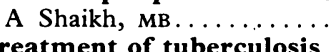

Treatment of tuberculosis

D Robinson, MD...

Abortion law reform

Judith K Bury, MB .............. 1698

niform style for biomedical journals

Cytological diagnosis of cows' milk

protein intolerance

D Bentley, MSC, MRCP

Patients' responses to barium $x$-ray

studies

M Goldman, MB, DMRD.

Recurrent vasculitis with beta-

haemolytic streptococcal infections

C T C Kennedy, MRCP, and others.......

Hazard of chemical sympathectomy

R A Boas, FFARAcs, and others........ 1700

Treatment of ulcerative colitis

B D Lask, MRCPSYCH. . . . . . . . . . 1700

A Russian visit

W H Vennells, MB

Heart-rate response to standing as a test

for automatic neuropathy

D J Ewing, MRCP, and others.
Surgical haemorrhage in patients given prophylactic heparin

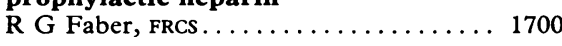

The other crisis of health care

C Reisner, MRCP............... 1700

The "Medical Directory"

$\mathrm{N}$ Young, $\mathrm{MB} \ldots \ldots \ldots \ldots \ldots \ldots \ldots . \ldots 1701$

Future of British anaesthetics

A Padfield, Ffarcs............. 1701

Private outpatient diagnostic services

R Eban, FRCR................ 1701

Money for old rope

S P Linton, MRCP........... 1701

Preregistration posts

D E Lee, FFARCS.

Abuse of Form Med 3

J G H Sheppard, MRCGP............ 1702

Points from Letters The finger in the urine (Lieutenant-Colonel H C M Walton); Diagnosis and treatment (D S McLaren); Respiratory complications of rheumatoid disease (M A Wajed); Migraine in childhood (R T D Fitzgerald); Cardiac signs for students (A Gilston); The postcoital test: what is normal? (A A Templeton); Review Body's Report (T

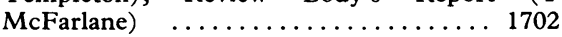

Correspondents are urged to write briefly so that readers may be offered as wide a selection of letters as possible. So many are being received that the omission of some is inevitable. Letters must be signed personally by all their authors.

\section{Gynaecological laparoscopy}

SIR,-In 1972 you published a paper by Professor D G Julian and myself on cardiac arrhythmias associated with laparoscopy. ${ }^{1}$ The anaesthetic method employed in that investigation was subsequently heavily criticised in your correspondence columns because in the cases we reported endotracheal intubation was not performed, ventilation was spontaneous, and a small dose of non-depolarising muscle relaxant was given. That most anaesthetists agreed with the criticisms is obvious from the report of the working party of the confidential inquiry into gynaecological laparoscopy conducted by the Royal College of Obstetricians and Gynaecologists, recently published ${ }^{2}$ (see leading article, $\mathrm{p}$ 1650). This shows that during the period covered by the inquiry (April 1976 to March 1977), of the 50247 operations reported, only $9.6 \%$ of the patients were not intubated and only $14 \%$ breathed spontaneously. Indeed the working party states: "In such a potentially hazardous situation, it seemed surprising that nearly $10 \%$ of all cases (4750) were managed using a face mask."

Nevertheless 4750 is a very considerable number and if the potential hazard is so great one must have expected several mishaps to have occurred. This singularly failed to happen, the overall complication rate being 1612 of $42829(3.8 \%)$ with controlled ventilation as against 189 of $6990(2.7 \%)$ with spontaneous ventilation. This difference is overwhelmingly statistically significant, and the working party's explanation that it could well be due to the fact that patients were intubated when things went wrong is wishful thinking at best.

One must admit that the way in which the data have been presented in the report, particularly the over-use of crude complication rates, is unlikely to shed much light on many of the problems. The method of anaesthesia is not going to affect many of the listed complications such as haemorrhage into the abdomina wall. However, it is contended that the use of spontaneous respiration and a face mask will lead to problems of inhalation of stomach contents and respiratory inadequacy. In fact the incidence of regurgitation during surgery was nil. Of 50247 patients, not one regurgitated stomach contents during the period of the pneumoperitoneum. Cardiac arrest occurred nine times and there were in addition four deaths. All these cases occurred in patients who had been intubated and whose ventilation was controlled, so it cannot be said that major catastrophes occurred more frequently in the non-intubated, selfventilating group. Of the 38 patients who developed "anaesthetic complications" as surgical ones, only one breathed spontaneously with a mask. Where then is the evidence for the "hazard" of not intubating ?

The report may also be criticised on two further major points. Firstly, the reluctance to diagnose what is almost certainly the most important cause of death, gas embolism. Only one of the four deaths is so designated while one other was clearly so and a third arguably so. Then there were the nine patients with cardiac arrest who were resuscitated. These seem to have been grouped together as if cardiac arrest were an inescapable feature of general anaesthesia. I would maintain that virtually the only two possible causes of cardiac arrest in intubated and ventilated patients are gas embolism and incorrect placement of the endotracheal tube in the oesophagus. The latter could only be associated with successful resuscitation if the incorrect placement were diagnosed and corrected. Thus it seems likely that virtually all these cases were of gas embolism.

Secondly, one must argue with the conclusion of the working party that sterilisation carried out at the time of termination of pregnancy carries no extra risk. This is based on the crude complication rate, which is a ridiculous index of the extra risk, which is solely in terms of gas embolism. One of the four deaths took place in a pregnant patient and there are no data regarding the nine cardiac arrests. Only $6.6 \%$ of patients in the survey were pregnant. Until better proof of the safety of the combined procedure is available the conclusion of the working party is reprehensible.

Having made these somewhat severe criticisms, may I nevertheless congratulate the working party for undertaking this mammoth task, and for the data they have accumulated.

\section{B ScotT}

Department of Anaesthetics,

Royal Infirmary Edinburgh

\section{Scott, D B, and Julian, D G, British Medical fournal, $1972,1,411$ \\ Gynaecological Laparoscopy. The Report of the Working Party of the Confidential Enquiry into Gynaecological Laparoscopy, eds G Chamberlain and J C Brown. London, Royal College of Obstetricians and
Gynaecologists, 1978.}

\section{Rubella vaccination}

SIR,-Although we feel that more should be done to reduce the incidence of rubella infection during pregnancy, we cannot agree with Dr Leonora A Crawford (3 June, p 1585) that rubella vaccination for both boys and girls is desirable. As long as 20 years may 